Helo Rubens de Oliveira Filho ${ }^{1}$

Mára Teixera Dória'

José Roberto Morales Piato'

JOSÉ MARIA SOARES JUNIOR'

JOSÉ ROBERTO FILASSI ${ }^{1}$

EDMUND ChADA BARACAT ${ }^{1}$

MARCOS DesidérIo RICCI'

Original Article

Keywords

Breast neoplasms/pathology Lymphatic metastasis/diagnosis Lymph nodes/pathology Lymphadenectomy

Palavras-chave

Neoplasias da mama/patologia Metástase linfática/diagnóstico Linfonodos/patologia Linfadenectomia

\title{
Criteria for prediction of metastatic axillary lymph nodes in early-stage breast cancer
}

\author{
Critérios para predição de metástases axilares em \\ câncer de mama em estádio clínico inicial
}

Abstract

PURPOSE: To estimate the likelihood of axillary lymph node involvement for patients with early-stage breast cancer, based on a variety of clinical and pathological factors. METHODS: A retrospective analysis was done in hospital databases from 1999 to 2007. Two hundred thirty-nine patients were diagnosed with early-stage breast cancer. Predictive factors, such as patient age, tumor size, lymphovascular invasion, histological grade and immunohistochemical subtype were analyzed to identify variables that may be associated with axillary lymph node metastasis. RESULTS: Patients with tumors that are negative for estrogen receptor, progesterone receptor, and HER2 had approximately a $90 \%$ lower chance of developing lymph node metastasis than those with luminal A tumors (e.g., ER+ and/or PR+ and HER2) - Odds Ratio: $0.11 ; 95 \%$ confidence interval: $0.01-0.88 ; p=0.01$. Furthermore, the risk for lymph node metastasis of luminal $A$ tumors seemed to decrease as patient age increased, and it was directly correlated with tumor size. CONCLUSION: The molecular classification of early-stage breast cancer using immunohistochemistry may help predicting the probability of developing axillary lymph node metastasis. Further studies are needed to optimize predictions for nodal involvement, with the aim of aiding the decision-making process for breast cancer treatment.

\section{Resumo}

OBJETIVO: Estimar a probabilidade de acometimento linfonodal em pacientes com câncer de mama inicial, baseado em fatores clínicos e patológicos. MÉTODOS: Foi realizada uma análise retrospectiva de 1999 a 2007 dos bancos de dados do hospital. Um total de 239 pacientes foram diagnosticados com câncer de mama em estádio inicial. Fatores preditivos como idade, tamanho do tumor, presença de invasão linfovascular, grau histológico e subtipo imunoistoquímico foram analisados para identificar possíveis variáveis associadas com a presença de metástases axilares. RESULTADOS: Pacientes com tumores negativos para receptor de estrogênio, receptor de progesterona e HER2 tiveram aproximadamente $90 \%$ menos chance de terem metástases axilares do que pacientes com tumores luminais A (por exemplo, ER+ e/ou PR+ e HER2) - Odds Ratio: 0, 11 ; intervalo de confiança de 95\%: 0,0 1-0,88; $\mathrm{p}=0,013$. Além disso, o risco de metástases axilares para tumores luminais $A$ diminuiu com o aumento da idade e se correlacionou diretamente com o tamanho do tumor. CONCLUSÃO: A classificação molecular do câncer de mama em estádio inicial utilizando a imunoistoquímica pode ajudar a predizer a probabilidade de encontrar metástases axilares. Novos estudos são necessários para otimizar essa predição, auxiliando no processo de decisão do tratamento relacionado ao câncer de mama.

Correspondence

Maíra Teixeira Dório Department of Obstetrics and Gynecology, Universidade de São Paulo Avenida Doutor Enéas Carvalho de Aguiar, 255 - 10 anda

CEP: 05403-000

São Paulo (SP), Brazil

Received

$04 / 02 / 2015$

Accepted with modifications

$06 / 18 / 2015$
Department of Obstetrics and Gynecology, Universidade de São Paulo - USP - São Paulo (SP), Brazil. 'Department of Obstetrics and Gynecology, Universidade de São Paulo - USP - São Paulo (SP), Brazil.

Conflict of interests: none 


\section{Introduction}

The surgical treatment of breast cancer has evolved substantially over the past few decades. Extensive surgical resection gave rise to a more conservative approach. To determine whether breast cancer dissemination has occurred in patients with a clinically node-negative axilla, sentinel lymph node biopsies (SLNBs) are currently the standard technique. The SLNB is associated with lower rates of morbidity and lymphedema compared to axillary lymph node dissection (ALND) $)^{1-4}$. However, it is still an invasive procedure and morbidity, including pain, paraesthesia and lymphedema, of such technique exists ${ }^{1,3-6}$.

Around 65 to $70 \%$ of all SLNBs are negative ${ }^{7}$, and their removal has not been shown to provide any significant survival benefit ${ }^{8}$. Moreover, the impact of prognostic information about axillary lymph node status on the decision-making process regarding breast cancer treatment is currently considered less important than it was previously. In addition, adjuvant treatment is increasingly being recommended to women with negative nodes to breast cancer, thus treatments are more tailored towards the biological features of each disease? .

Moreover, in more than half of all cases involving sentinel lymph nodes (SLNs), axillary clearance fails to reveal any other metastatic lymph nodes present ${ }^{7,10}$. Furthermore, in a randomized study by the American College of Surgeons' Oncology Group (the Z0011 trial) ${ }^{10}$, it was demonstrated that ALND can be omitted for patients who have clinical T1/T2 breast cancer with up to two positive SLNs, and who are treated with breast-conserving surgery, whole breast irradiation, and adjuvant systemic treatment. Thus, this recent data raises doubts on the role of SNLB itself and makes us consider if we can safely omit SLNB in selected cases ${ }^{11,12}$. Therefore, prognostic tools are needed to predict which patients have a higher risk of nodal involvement and which ones can be spared of an unnecessary axillary surgery.

To date, a variety of clinical and pathological factors has been identified as independent predictors of axillary lymph node involvement for patients with early-stage breast cancer. These include clinical palpability ${ }^{13-17}$, tumor size $^{7,13-23,24}$, lymphovascular invasion (LVI) $)^{7,13-18,20,22,23}$, tumor grade ${ }^{13,16,17,21}$, tumor multifocality ${ }^{7,20}$, tumor loca$\operatorname{tion}^{20,22}$, and patient age $\mathrm{e}^{14,18-21}$. More recently, the gene expression profile of invasive breast carcinoma has also been considered in the determination of prognosis for early-stage breast cancer patients ${ }^{25,26}$. While these types of data confirm that breast cancer is a heterogeneous disease, hierarchical clustering of complex gene expression patterns have also identified three types of breast carcinoma: luminal-like, basal-like, and HER2-like ${ }^{27,28}$. In a study conducted by Nielsen et al. ${ }^{29}$, these molecular subtypes were found using immunohistochemistry (IHC), and the results were linked to prognosis. Thus, breast cancer subtypes may provide another predictive criterion for lymph node metastases.

Ideally, a predictor of axillary lymph node metastasis should be highly accurate, easily reproducible, cost-effective, and induce minimal, if any, damage or side effects on patients. The known methods for predicting lymph node involvement in breast cancer include: axillary dissection, sentinel node biopsy, clinical assessment, and evaluation of imaging methods. For the present study, the aim was to estimate the likelihood of axillary lymph node involvement for patients with early-stage breast cancer, based on a variety of clinical and pathological factors. In particular, breast cancer immunohistochemical subtypes were analyzed.

\section{Methods}

\section{Study subjects}

This retrospective, cross-sectional study analyzed the medical records of patients of any ages diagnosed with non-metastatic invasive breast cancer, who were treated between 1999 and 2007 at the breast cancer unit in the Discipline of Gynecology, Hospital das Clínicas, School of Medicine, Universidade de São Paulo. A single pathologist monitored all histopathological studies.

These patients underwent surgery in order that the invasive ductal carcinomas of less than $5 \mathrm{~cm}$ in diameter, as measured by caliper, were surgically excised. Axillary lymph node staging was achieved through ALND or SLNB. Patients negative for SLN metastasis who did not undergo axillary dissection were considered without lymph node metastasis. Both pregnant women and patients undergoing neoadjuvant treatment (e.g., chemotherapy, hormone therapy, or radiotherapy) were excluded. All patients without completed records, and for whom a histopathological review was not possible, were also excluded.

The following factors were examined with regard to their potential to predict axillary lymph node involvement: patient age, tumor size, LVI, estrogen receptor (ER), progesterone receptor (PR), and HER2 status. These patients were further subdivided into age as follows: $<40$ years, $40-55$ years, and $>55$ years. In addition, patients were divided into two groups according to the clinical T stage of their tumor at diagnosis: $0-2 \mathrm{~cm}$ (T1) and $2-5 \mathrm{~cm}(\mathrm{~T} 2)$.

\section{Histopathological analysis}

All specimens obtained during breast resections and axillary lymphadenectomies were paraffin-embedded for histopathological analysis. Nodes of the lymphoadipose 
axillary tissue were histologically dissected, counted, and analyzed. IHC using the streptavidin biotin peroxidase technique was used to analyze expression of ER, PR, and HER 2 in resected tumor tissues and percutaneous biopsy samples. Levels of ER and PR were considered positive if more than $10 \%$ of the neoplastic cells present showed membrane staining. HER patients were considered HER 2 positive with an IHC score of $3+$. When an IHC score of $2+$ was obtained, fluorescence in situ hybridization (FISH) was conducted to define positivity. Lastly, an IHC score of $1+$ was considered negative for HER2 expression. Patients were subsequently grouped according to immunohistochemical subtype as follows: luminal $\mathrm{A}\left(\mathrm{ER}^{+}\right.$

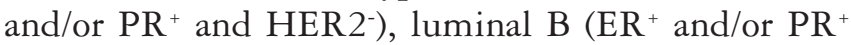
and $\left.\mathrm{Her} 2^{+}\right)$, HER $2\left(\mathrm{ER}^{-} / \mathrm{PR}^{-} / \mathrm{Her} 2^{+}\right)$, and triple-negative (ER-/PR-/Her 2-).

\section{Statistical analysis}

In order to evaluate the presence of metastases in the axilla as to clinical and prognostic factors, the absolute and relative frequencies, chi-square test, or likelihood ratios and calculated Odds Ratios (OR) were determined, using a $95 \%$ confidence interval (CI) as a measure of association.

Associations between variables of interest and metastasis were separately analyzed for each subtype based on IHC results. Neither a likelihood ratio test nor Fisher's exact test were applied. The tests were performed using a significance level of $5 \%$.

\section{Ethical aspects}

The Research Ethics Committee of School of Medicine, University of São Paulo, approved the study. The study was conducted based on the guidelines of the National Health Council on "research ethics" published in 1966, and according to Resolution CNS 196/96, "Guidelines and Standards for Research involving Human Beings," which repealed the previous resolution.

\section{Results}

For this cohort, 163/239 (68.2\%) patients were diagnosed with negative axillary metastasis, while 76/239 $(31.8 \%)$ patients were positive. Patient and tumor characteristics, based on the axillary lymph node status, are presented in Table 1. These cases were also divided into subtypes according to the IHC results obtained. A higher prevalence of luminal A and B subtypes was seen, followed by triple-negative and HER2 subtypes (Figure 1).

Immunohistochemical subtype, tumor size and LVI were the only factors significantly associated with lymph node status (Table 1). Moreover, patients with triplenegative tumors had approximately a $90 \%$ lower chance of developing lymph node metastasis compared to those with luminal A tumors $(\mathrm{OR}=0.11 ; 95 \% \mathrm{CI} 0.01-0.88$; $\mathrm{p}=0.01)$. In contrast, $\mathrm{T} 2$ tumors had a $143 \%$ higher chance of axillary lymph node metastasis compared to T1 tumors $(\mathrm{OR}=2.43 ; 95 \% \mathrm{CI} 1.38-4.29 ; \mathrm{p}=0.002)$. Information about LVI was available for 204 of the 239 patients and was also a strong predictive factor for axillary lymph node involvement $(\mathrm{OR}=4.84 ; 95 \% \mathrm{CI} 2.56-9.17$; $\mathrm{p}<0.001)$.

Subtypes as defined by immunohistochemistry were also stratified according to patient age and tumor size in order to verify if there was a significant correlation between these factors and lymph node status (Tables 2 and 3). For luminal A tumors, the risk for lymph node metastasis was found to decrease with age from youngest to oldest $(p<0.05)$, with

Table 1. Patient and tumor characteristics and related statistical analysis

\begin{tabular}{|c|c|c|c|c|c|}
\hline Factor & n & $\begin{array}{c}\text { Node- } \\
\text { negative } \\
\text { n }\end{array}$ & $\begin{array}{c}\text { Node- } \\
\text { positive } \\
\text { n }\end{array}$ & OR (95\%Cl) & p-value \\
\hline Age groups & & & & & 0.04 \\
\hline$<40$ years & 18 & 11 & 7 & 1.00 & \\
\hline $40-55$ years & 104 & 63 & 41 & $1.02(0.37-2.85)$ & \\
\hline$>55$ years & 114 & 87 & 27 & $0.49(0.17-1.38)$ & \\
\hline Tumor size & & & & & 0.002 \\
\hline $0-2 \mathrm{~cm}$ & 159 & 119 & 40 & 1.00 & \\
\hline $2-5 \mathrm{~cm}$ & 80 & 44 & 39 & $2.43(1.38-4.29)$ & \\
\hline Molecular subtype & & & & & 0.01 \\
\hline Luminal A & 178 & 120 & 58 & 1.00 & \\
\hline Luminal B & 33 & 21 & 12 & $1.18(0.54-2.57)$ & \\
\hline Her2+/ER- & 9 & 4 & 5 & $2.59(0.67-9.99)$ & \\
\hline Triple-negative & 19 & 18 & 1 & $0.11(0.01-0.88)$ & \\
\hline LVI & & & & & $<0.001$ \\
\hline Negative & 135 & 109 & 26 & 1.00 & \\
\hline Positive & 69 & 32 & 37 & $4.84(2.56-9.17)$ & \\
\hline \multicolumn{6}{|l|}{ Histological grade } \\
\hline 1 & 40 & 29 & 11 & 1.00 & 0.5 \\
\hline 2 & 137 & 96 & 41 & $1.12(0.51-2.45)$ & \\
\hline 3 & 42 & 26 & 16 & $1.62(0.63-4.12)$ & \\
\hline
\end{tabular}

LVI: Iymphovascular invasion; OR: odds ratio; $\mathrm{Cl}$ : confidence interval.

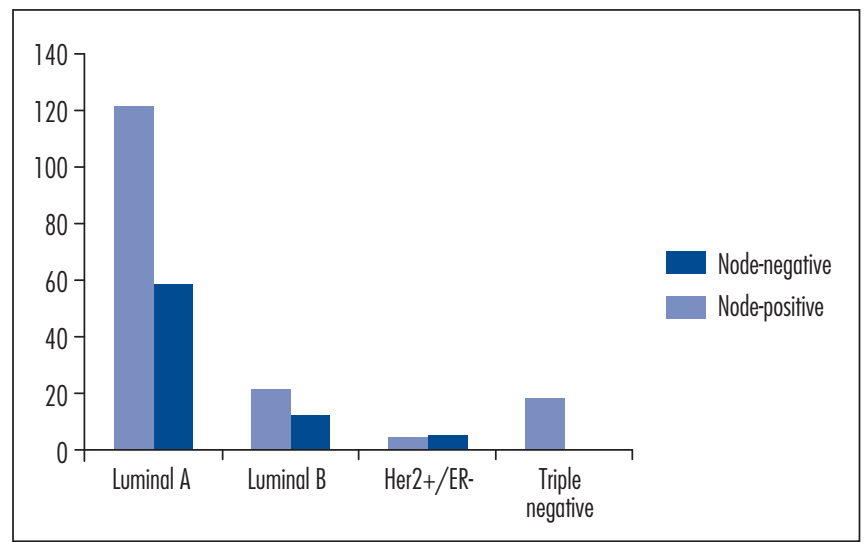

Figure 1. Frequency of nodal positivity according to molecular subtype 
Table 2. Molecular subtypes according to patient's age groups and node status

\begin{tabular}{|c|c|c|c|c|c|c|c|c|c|c|c|c|}
\hline \multirow{3}{*}{ Molecular subtype } & \multicolumn{12}{|c|}{ Age groups } \\
\hline & \multicolumn{4}{|c|}{$<40$ years } & \multicolumn{4}{|c|}{$40-55$ years } & \multicolumn{4}{|c|}{$>55$ years } \\
\hline & \multicolumn{2}{|c|}{ Node-negative } & \multicolumn{2}{|c|}{ Node-positive } & \multicolumn{2}{|c|}{ Node-negative } & \multicolumn{2}{|c|}{ Node-positive } & \multicolumn{2}{|c|}{ Node-negative } & \multicolumn{2}{|c|}{ Node-positive } \\
\hline Luminal A & 6 & 50 & 6 & 50 & 46 & 59 & 32 & 41 & 67 & 77.9 & 19 & 32.1 \\
\hline Luminal B & 2 & 100 & 0 & 0 & 9 & 52.9 & 8 & 47.1 & 9 & 69.2 & 4 & 30.8 \\
\hline HER2 ${ }^{+} /$ER $^{-}$ & 0 & 0 & 1 & 100 & 2 & 66.7 & 1 & 33.3 & 2 & 40 & 3 & 60 \\
\hline
\end{tabular}

Table 3. Molecular subtypes according to fumor size and axillary node status

\begin{tabular}{lcccccccc}
\hline & \multicolumn{8}{c}{ Tumor size } \\
\cline { 2 - 10 } Molecular subtype & \multicolumn{3}{c}{ 0-2 cm } & \multicolumn{3}{c}{ 2-5 cm } \\
\cline { 2 - 10 } & $\begin{array}{c}\text { Node- } \\
\text { negative }\end{array}$ & $\begin{array}{c}\text { Node- } \\
\text { positive }\end{array}$ & $\begin{array}{c}\text { Node- } \\
\text { negative }\end{array}$ & $\begin{array}{c}\text { Node- } \\
\text { positive }\end{array}$ \\
\cline { 2 - 10 } & $\mathbf{n}$ & $\%$ & $\mathrm{n}$ & $\%$ & $\mathrm{n}$ & $\%$ & $\mathrm{n}$ & $\%$ \\
\hline Luminal A & 90 & 75 & 30 & 25 & 30 & 51.7 & 28 & 48.3 \\
Luminal B & 16 & 69.6 & 7 & 30.4 & 5 & 50 & 5 & 50 \\
Her2+/ER- & 3 & 60 & 2 & 40 & 1 & 25 & 3 & 75 \\
Triple-negative & 10 & 90.9 & 1 & 9.1 & 8 & 100 & 0 & 0 \\
\hline
\end{tabular}

patients younger than 40 years presenting the highest risk of metastasis $(50.0 \%)$ and patients older than 55 years, the lowest $(32.1 \%)$. Moreover, the rate of lymph node involvement for the luminal A subtype was found directly correlated with tumor size. For example, $25 \%$ of tumors of less than $2 \mathrm{~cm}$ in diameter were followed by lymph node metastasis, while $48.3 \%$ of tumors with diameters ranging from $2 \mathrm{~cm}$ to $5 \mathrm{~cm}$ were joined by lymph node metastasis $(\mathrm{p}<0.05)$. In contrast, stratification of the other immunohistochemical subtypes according to patient's age and tumor size could not find any significant associations with an increased risk of axillary lymph node metastasis.

Overall, molecular subtype luminal A, larger tumors, younger patient's age and the presence of LVI were identified as predictors of axillary lymph node metastasis. However, these associations were not seen in patients with triple-negative tumors, where the possibility of lymph node metastasis remained very low, regardless of patient's age and tumor size.

\section{Discussion}

Results of this study show that the division of breast cancers into immunohistochemistry subtypes carries predictive information for the presence of axillary lymph node involvement at diagnosis. In particular, patients with triple-negative tumors had the lowest incidence of axillary lymph node metastasis, regardless of patient's age or tumor size. In comparison, another study analyzed a microarray of 4,444 early-stage breast cancer tissues, and the risk of lymph node involvement for patients with a basal phenotype was almost half that of patients with a luminal subtype ${ }^{17}$.

Results of the present study also demonstrate that the risk for lymph node metastasis of luminal A tumors decreases with patient's age from youngest to oldest, and is directly correlated with tumor size. In another study, in which tumors were also analyzed according to molecular subtype, a very specific correlation pattern between tumor size and the probability of a positive SLNB was observed $^{30}$. Furthermore, tumor size was found to be a major determinant of axillary metastasis development in HER2 positive and ER positive (either HER2 negative or positive) subgroups. Other authors have also demonstrated a higher risk of lymph node metastasis in patients with HER2 overexpression ${ }^{31,32}$. The present study did not find this correlation, which can be explained by the small number of patients with HER2+.

Bevilacqua et al. ${ }^{20}$ developed a nomogram to predict the presence of SLN metastasis using an area under the curve (AUC) value of 0.754 as a cutoff point. The clinicopathological characteristics used to generate the nomogram were tumor type, size and location, as well as patient's age, LVI, multi-focality, nuclear grade, ER status, and

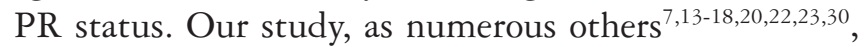
have also demonstrated that LVI is a powerful predictor of axillary metastasis. However, from a patient's management perspective, pathological information on LVI is available only after a surgical procedure has been performed. It should also be noted that the nomogram cited earlier did not use molecular subtype classification ${ }^{20}$, and this has been shown to be of value in predicting axillary lymph node status ${ }^{17,21,23,30,33,34}$.

In the present study, axillary metastases were not detected in $68.2 \%$ of the examined patients. Correspondingly, for these cases, SLNBs did not provide any additional information regarding the need for adjuvant treatment and may lead to some morbidity ${ }^{1,3-6}$. It is conceivable that an analysis of the primary tumor, rather than the axillary lymph nodes, may provide better guidance for adjuvant treatments. Furthermore, advances in the prognostic tools that provide clinical, pathological, and molecular information may eventually facilitate the identification of patients with a very low risk of axillary lymph node 
involvement, and thus, SLNBs should not be performed for these patients. However, there is currently no single marker or combination of markers that provide sufficient accuracy to obviate the need for axillary staging.

There are some limitations in the present study. Firstly, our report based the axillary lymph node status on results from a mixture of complete axillary node dissection and sentinel lymph node procedure. However, it has been previously shown that predictors for axillary lymph node involvement are independent of how the lymph node resection was performed ${ }^{7}$. Secondly, another weakness may be that we concentrated the prediction mostly on immunohistochemical subtypes that do not have a perfect classification with several overlaps across the different subtypes. A positive point of our study is that only one pathologist confirmed the analysis for ER, PR and HER2. Furthermore, we defined HER 2 positive according to the membrane staining when there was not either a DAKO score $3+$ or $2+$ with a positive FISH test.
Molecular classification of early-stage breast cancer by IHC may aid predictions of axillary lymph node metastasis. The present results indicate that younger patients (e.g., < 40 years) with larger, luminal A subtype tumors and the presence of LVI have the highest likelihood of lymph node involvement. Conversely, a triple-negative subtype is predictive of a lower incidence of axillary lymph node metastasis. Further studies are needed to optimize predictions of nodal involvement, which improve the decision-making process for breast cancer treatment. Moreover, these predictions need to involve a stratification of patients according to those who would benefit from a nonsurgical approach to axilla treatment.

\section{Acknowledgements}

To Filomena Marino Carvalho for the knowledge shared and help with the pathological analysis of all study patients.

\section{References}

1. Veronesi U, Paganelli G, Viale G, Luini A, Zurrida S, Galimberti $V$, et al. A randomized comparison of sentinel-node biopsy with routine axillary dissection in breast cancer. $N$ Engl J Med. 2003;349(6):546-53

2. Mansel RE, Fallowfield L, Kissin M, Goyal A, Newcombe RG, Dixon $J M$, et al. Randomized multicenter trial of sentinel node biopsy versus standard axillary treatment in operable breast cancer: the ALMANAC trial. J Natl Cancer Inst. 2006;98(9):599-609.

3. Langer I, Guller U, Berclaz G, Koechli OR, Schaer G, Fehr MK, et al. Morbidity of sentinel lymph node biopsy (SLN) alone versus SLN and completion axillary lymph node dissection after breast cancer surgery: a prospective Swiss multicenter study on 659 patients. Ann Surg. 2007;245(3):452-61.

4. Helms G, Kühn T, Moser L, Remmel E, Kreienberg R. Shoulderarm morbidity in patients with sentinel node biopsy and complete axillary dissection - data from a prospective randomised trial. Eur J Surg Oncol. 2009;35(7):696-701.

5. Lucci A, McCall LM, Beitsch PD, Whitworth PW, Reintgen DS, Blumencranz PW, et al. Surgical complications associated with sentinel lymph node dissection (SLND) plus axillary lymph node dissection compared with SLND alone in the American College of Surgeons Oncology Group Trial Z001 1. J Clin Oncol. 2007;25(24):3657-63.

6. McLaughlin SA, Wright M, Morris KT, Giron GL, Sampson MR, Brockway JP, et al. Prevalence of lymphedema in women with breast cancer 5 years after sentinel lymph node biopsy or axillary dissection: objective measurements. J Clin Oncol. 2008;26(32):5213-9.

7. Viale G, Zurrida S, Maiorano E, Mazzarol G, Pruneri G, Paganelli $G$, et al. Predicting the status of axillary sentinel lymph nodes in 4351 patients with invasive breast carcinoma treated in a single institution. Cancer. 2005;103(3):492-500.

8. Chua B, Ung O, Taylor R, Boyages J. Frequency and predictors of axillary lymph node metastases in invasive breast cancer. ANZ J Surg. $2001 ; 71(12): 723-8$.
9. Goldhirsch A, Ingle JN, Gelber RD, Coates AS, Thürlimann B, Senn HJ, et al. Thresholds for therapies: highlights of the St Gallen International Expert Consensus on the primary therapy of early breast cancer 2009. Ann Oncol. 2009;20(8):1319-29.

10. Giuliano AE, Hunt KK, Ballman KV, Beitsch PD, Whitworth PW, Blumencranz PW, et al. Axillary dissection vs no axillary dissection in women with invasive breast cancer and sentinel node metastasis: a randomized clinical trial. JAMA. $2011 ; 305(6): 569-75$.

11. Patani NR, Dwek MV, Douek M. Predictors of axillary lymph node metastasis in breast cancer: a systematic review. Eur J Surg Oncol. 2007;33(4):409-19

12. Gentilini $O$, Veronesi U. Abandoning sentinel lymph node biopsy in early breast cancer? A new trial in progress at European Institute of Oncology of Milan (SOUND: Sentinel node vs Observation after axillary UltraSouND). Breast. 2012;21 (5):678-81.

13. Barth A, Craig PH, Silverstein M. Predictors of axillary lymph node metastases in patients with $\mathrm{T} 1$ breast carcinoma. Cancer. 1997;79(10): 1918-22.

14. Olivotto IA, Jackson JS, Mates D, Andersen S, Davidson W, Bryce CJ, et al. Prediction of axillary lymph node involvement of women with invasive breast carcinoma: a multivariate analysis. Cancer. 1998;83(5):948-55

15. Silverstein M, Gierson ED, Waisman JR, Colburn WJ, Gamagami P. Predicting axillary node positivity in patients with invasive carcinoma of the breast by using a combination of T category and palpability. J Am Coll Surg. 1995;180(6):700-4.

16. Silverstein M, Skinner KA, Lomis TJ. Predicting axillary nodal positivity in 2282 patients with breast carcinoma. World J Surg. $2001 ; 25(6): 767-72$

17. Crabb SJ, Cheang MC, Leung S, Immonen T, Nielsen TO, Huntsman $\mathrm{DD}$, et al. Basal breast cancer molecular subtype predicts for lower incidence of axillary lymph node metastases in primary breast cancer. Clin Breast Cancer. 2008;8(3):249-56. 
18. Gajdos C, Tartter PI, Bleiweiss IJ. Lymphatic invasion, tumor size, and age are independent predictors of axillary lymph node metastases in women with T1 breast cancers. Ann Surg. 1999;230(5):692-6.

19. Gann PH, Colilla SA, Gapstur SM, Winchester DJ, Winchester DP. Factors associated with axillary lymph node metastasis from breast carcinoma: descriptive and predictive analyses. Cancer. 1999;86(8):1511-9.

20. Bevilacqua L, Kattan MW, Fey JV, Cody HS 3rd, Borgen PI, Van Zee KJ. Doctor, what are my chances of having a positive sentinel node? A validated nomogram for risk estimation. J Clin Oncol. 2007;25(24):3670-9.

21. Van Calster B, Bempt IV, Drijkoningen M, Pochet N, Cheng J, Van Huffel $S$, et al. Axillary lymph node status of operable breast cancers by combined steroid receptor and HER-2 status: triple positive tumours are more likely lymph node positive. Breast Cancer Res Treat. 2009;1 13(1):181-7.

22. Capted J, Martel P, Charitansky H, Lim YK, Ferron G, Battle L, et al. Factors predicting the sentinel node metastases in $\mathrm{Tl}$ breast cancer tumor: an analysis of 1416 cases. Eur J Surg Oncol. 2009;35(12): 1245-9.

23. Lee JH, Kim SH, Suh YJ, Shim BY, Kim HK. Predictors of axillary lymph node metastases (ALNM) in a Korean population with T1-2 breast carcinoma: triple negative breast cancer has a high incidence of ALNM irrespective of the tumor size. Cancer Res Treat. 2010;42(1):30-6.

24. Sawaki M, Idota Al, Ichikawa M, Gondo N, Horio A, Kondo N, et al. Impact of intrinsic subtype on predicting axillary lymph node metastasis in breast cancer. Oncol Lett. 2014;8(4):1707-12.

25. Rakha EA, Reis-Filho JS, Baehner F, Dabbs DJ, Decker T, Eusebi $V$, et al. Breast cancer prognostic classification in the molecular era: the role of histological grade. Breast Cancer Res. 2010;12(4):207.
26. Reis-Filho JS, Pusztai L. Gene expression profiling in breast cancer: classification, prognostication, and prediction. Lancet. $2011 ; 378(9805): 1812-23$

27. Perou $C M$, Sorlie T, Eisen MB, van de Rijin M, Jeffrey SS, Rees $\mathrm{CA}$, et al. Molecular portraits of human breast tumours. Nature. 2000;406(6797):747-52.

28. Sorlie T, Perou CM, Tibshirani R, Aas T, Geisier S, Johnsen H, et al. Gene expression patterns of breast carcinomas distinguish tumor subclasses with clinical implications. Proc Natl Acad Sci USA. $2001 ; 98(19): 10869-74$.

29. Nielsen TO, Hsu FD, Jensen K, Cheang M, Karaca G, Hu Z, et al. Immunohistochemical and clinical characterization of the basal-like subtype of invasive breast carcinoma. Clin Cancer Res. 2004; 10(16):5367-74.

30. Lu X, Lu X, Wang ZC, Iglehart JD, Zhang X, Richardson AL. Predicting features of breast cancer with gene expression patterns. Breast Cancer Res Treat. 2008; 108(2):191-201.

31. Gulben K, Berberoglu U, Aydogan O, Kinas V. Subtype is a predictive factor of nonsentinel lymph node involvement in sentinel node-positive breast cancer patients. J Breast Cancer. 2014;17(4):370-5.

32. Yoo SH, Park IA, Chung YR, Kim H, Lee K, Noh DY, et al. A histomorphologic predictive model for axillary lymph node metastasis in preoperative breast cancer core needle biopsy according o intrinsic subtypes. Hum Pathol. 2015;46(2):246-54.

33. Reyal F, Rouzier R, Depont-Hazelzet B, Bollet MA, Pierga JY, Alran $S$, et al. The molecular subtype classification is a determinant of sentinel node positivity in early breast carcinoma. PLoS One. $2011 ; 6(5): \mathrm{e} 20297$.

34. Zhou W, He Z, Xue J, Wang M, Zha X, Ling L, et al. Molecular subtype classification is a determinant of non-sentinel lymph node metastasis in breast cancer patients with positive sentinel lymph nodes. PLoS One. 2012;7(4):e35881. 